\title{
Impact of Reaction Dynamics on Synthesis of Novel Nitrogen containing Aldehydes
}

\author{
RAJASHREE A. MARKANDEWAR ${ }^{1}$, HANFI M. ZIA² and M. A. BASEER ${ }^{2}$ \\ ${ }^{1}$ Department of Applied Chemistry, Ballarpur Institute of Technology, Ballarpur - 442 701, India. \\ ${ }^{2}$ Department of Chemistry, YeshwantMahavidyalaya, Nanded - 431 601, India.
}

http://dx.doi.org/10.13005/ojc/290432

(Received: September 09, 2013; Accepted: October 30, 2013)

\begin{abstract}
Impact of solvent dynamics, base employed and temperature conditions on the synthesis of novel Nitrogen containing aldehydes was studied.Piperazine, pyrrolidine and piperidine aldehydes were obtained in maximum yield and puritywith the $\mathrm{K}_{2} \mathrm{CO}_{3}$ base in presence of DMF solventand at $80^{\circ} \mathrm{C}$ temperatures. The synthesized compounds were characterized by IR, ${ }^{1} \mathrm{HNMR}$ and MS Spectroscopy.
\end{abstract}

Key words: Nitrogen-containing-aldehyde, Reaction dynamics, N-arylation.

\section{INTRODUCTION}

Nitrogen containing compounds are used as structural components of pharmaceuticals and agrochemicals due to their high biological activities'. There are many nitrogen containing chemicals, ranging from simple structural compounds as pyridine to complicated compounds as pharmaceutical ingredients and their number is growing rapidly year by year ${ }^{2}$.Pyrrolidine based compounds have wide application in pharmaceutics ranging from use in the treatment of cancer $^{3}$,obesity ${ }^{4}$, fungal and viral infections $^{5}$, HIV infection ${ }^{6}$ and diabetes ${ }^{7-8}$. Piperazine nucleus is one of the most important heterocycle, exhibiting remarkable pharmacological activities as anthelminitis ${ }^{9}$, anti- HIV agent, antanginals ${ }^{10}$, urological $^{11}$ and anticonvulsant compounds ${ }^{12}$. Piperidine and its derivatives are ubiquitous building blocks in the synthesis of pharmaceuticals compounds like anti depressant drug ${ }^{13-14}$ and vasolidators ${ }^{15}$. Piperidine is also commonly used in sequencing of DNA ${ }^{16}$ and in solid phase peptide synthesis ${ }^{17}$.

As per the review about recent trends in chemistry of pyrrolidine, piperazine and piperidine derivatives, their demand in pharmaceuticals is increasing and still lies scope for the exploration of pharmaco-kinetics of these compounds.

All these facts were driving force to study the synthesis of $4(-4 m e t h y l$ piperazine-I-yl) benzaldehyde, (4- pyrrolidin-I-yl) benzaldehyde and (4-piperidine-I-yl) benzaldehyde.The present work is concerned solely with the chemistry i.e. the yield of the above mentioned products, for which the dynamics of the environment (solvent, base and temperature) can be responsible. 


\section{Study of different parameters on the synthesis} of aldehyde

In continuation to explore the pharmaceutical significance of $\mathrm{N}$-arylated moiety, thepiperazine, piperidine and pyrrolidinemoieties, it was planned to conduct a thorough study of the different parameters on the yield of 4-(4-methyl-piperazineI-yl) benzaldehyde, (4-pyrrolidine-l-yl) benzaldelyde and (4-piperidine-I-yl) benzaldehyde. The systematic study was carried out keeping in view their significance on the yield by virtue of effect of bases, solvents and temperature conditions as depicted in Table 1-3.

Table 1: Effect of different bases

\begin{tabular}{lllcc}
\hline S. & Name of & \multicolumn{3}{c}{$\%$ Yield obtained } \\
\cline { 3 - 5 } No & Base Used & 1a & 1b & 1c \\
\hline 1. & $\mathrm{K}_{2} \mathrm{CO}_{3}$ & $92 \%$ & $94 \%$ & $89 \%$ \\
2. & $\mathrm{CsCO}_{3}$ & $88 \%$ & $90 \%$ & $80 \%$ \\
3. & $\mathrm{Na}_{2} \mathrm{CO}_{3}$ & $87 \%$ & $84 \%$ & $73 \%$ \\
4. & $\mathrm{KHCO}_{3}$ & $85 \%$ & $80 \%$ & $60 \%$ \\
5. & $\mathrm{NaHCO}_{3}$ & $80 \%$ & $76 \%$ & $50 \%$ \\
\hline
\end{tabular}

Table 2: Effect of different solvents

\begin{tabular}{lllll}
\hline S. & Name of & \multicolumn{3}{c}{$\%$ Yield obtained } \\
\cline { 3 - 5 } No & Base Used & 1a & 1b & 1c \\
\hline 1. & DMF & $95 \%$ & $96 \%$ & $90 \%$ \\
2. & DMSO & $90 \%$ & $89 \%$ & $84 \%$ \\
3. & Toluene & $70 \%$ & $65 \%$ & $62 \%$ \\
4. & Xylene & $75 \%$ & $75 \%$ & $50 \%$ \\
5. & Methanol & No & No & No \\
& & reaction & reaction & reaction \\
6. & Acetone & No & No & No \\
& & reaction & reaction & reaction \\
\hline
\end{tabular}

\section{EXPERIMENTAL}

All the melting points were carried out in open capillary tubes and are uncorrected. The Thin Layer Chromatography was performed on precoated silica plates and lodine vapor is used for visualization. IR spectra were recorded in $\mathrm{KBr}$ disc on Shimadzu FT-IR 8300 spectrophotometer. ${ }^{1} \mathrm{HNMR}$ spectra were recorded in DMSO-d6 on a Brucker Advance II- $400 \mathrm{MHz}$ Spectrometer using TMS as an internal standard. Mass spectra were recorded on VG7070H mass spectrometer.

\section{Synthesis of 4-(4-methyl piperazine-I-yl) benzaldehyde[1a]}

In $4.0 \mathrm{ml}$ of DMF, 1-methyl piperazine $(0.1$ gm. $0.001 \mathrm{~mol}$ ) was dissolved. To this solution $\mathrm{K}_{2} \mathrm{CO}_{3}$ (0.20gm, $0.00015 \mathrm{~mol})$ was added and heated at $80^{\circ} \mathrm{C}$ with stirring. After $30 \mathrm{~min} 4$-flurobenzaldehyde $(0.124 \mathrm{gm}, 0.001 \mathrm{~mol})$ was added and heating was continued for 6 hours. On completion of reaction, the reaction mixture was cooled and added drop wise to ice-water. The separated product was filtered and dried. The product obtained was pure and used further without any purification.(M.P. $60-62^{\circ} \mathrm{C}$ )

Table 3: Effect of different Temperature

\begin{tabular}{lllll}
\hline S. & Name of & \multicolumn{3}{c}{$\%$ Yield obtained } \\
\cline { 3 - 5 } No & Base Used & 1a & 1b & 1c \\
\hline 1) & $80-90^{\circ} \mathrm{C}$ & $92 \%$ & $86 \%$ & $90 \%$ \\
2) & $110-120^{\circ} \mathrm{C}$ & $55 \%$ & $60 \%$ & $50 \%$ \\
3) & $150-160^{\circ} \mathrm{C}$ & $\begin{array}{l}\text { Decom } \\
\text { posed }\end{array}$ & $\begin{array}{l}\text { Decom } \\
\text { posed }\end{array}$ & $\begin{array}{l}\text { Decom } \\
\text { posed }^{*}\end{array}$ \\
& & & &
\end{tabular}

*- no of spots formed on TLC

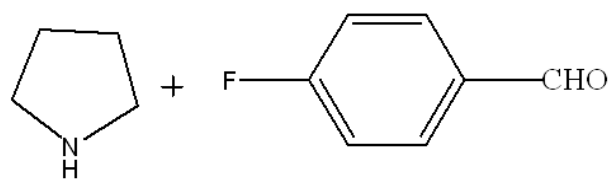

Spectral Analysis

IR:(cm-1): 1686 (C=O); 1561 (C=C).

${ }^{1} \mathrm{HNMR}: .(\mathrm{DMSO}) \delta \mathrm{ppm}: 2.0\left(\mathrm{~s}, 3 \mathrm{H}, \mathrm{CH}_{3}\right) ; 2.3$

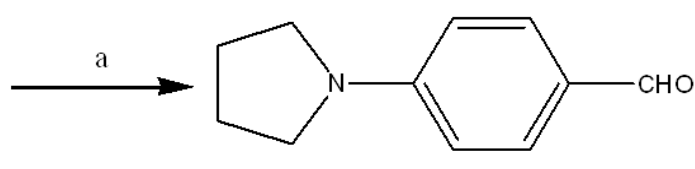

(t, $\left.4 \mathrm{~h}, \mathrm{CH}_{2}\right) ; 3.3\left(\mathrm{t}, 4 \mathrm{H} \mathrm{CH}_{2}\right) ; 7.2$ (dd, $2 \mathrm{H}$, aromatic) 8.1 (dd, $2 \mathrm{H}$, aromatic) ; $9.9(\mathrm{~s}, 1 \mathrm{H}, \mathrm{CHO})$

Mass: Mass (m/z): 204 
Synthesis of (4-Pyrrolidine-I-yl) benzaldehyde [1b]

In $4.0 \mathrm{ml}$ of DMF of pyrrolidine $(0.1 \mathrm{gm}$, $0.001 \mathrm{~mol}$ ) was dissolved. To this solution $\mathrm{K}_{2} \mathrm{CO}_{3}$ $(0.27 \mathrm{gm}, 0.002 \mathrm{~mol})$ was added and heated at $80^{\circ} \mathrm{C}$ with stirring. After $30 \mathrm{~min}$ 4- fluorobenzaldehyde
(0.174 gm, $0.001 \mathrm{~mol}$ ) was added and heating was continued for six hours. On completion of reaction, the reaction mixture was cooled and added dropwise to ice water. The separated product was filtered and dried. The product obtained was pure and used further without any purification (M.P- $88^{\circ} \mathrm{C}$ )

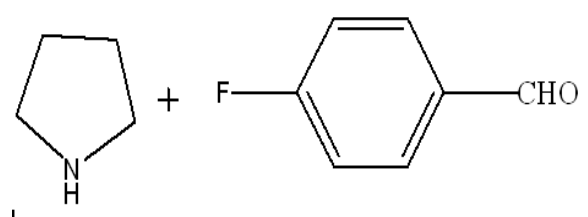

\section{Spectral Analysis}

IR: $\left(\mathrm{Cm}^{-1}\right): 1653(\mathrm{C}=\mathrm{O}) ; 1524(\mathrm{C}=\mathrm{C})$.

${ }^{1} \mathrm{HNMR}:(\mathrm{DMSO}) \delta \mathrm{ppm}: 2.2\left(\mathrm{t}, 4 \mathrm{H}, \mathrm{CH}_{2}\right), 3.2(\mathrm{t}, 4 \mathrm{H}$, $\mathrm{CH}_{2}$ ), 6.4 (d, 2H,aromatic) 7.7.(d, 2H,aromatic), 9.8 (s, $1 \mathrm{H} \mathrm{CHO}$.

Mass: Mass (m/z) $-175\left(M^{+}+i o n\right)$

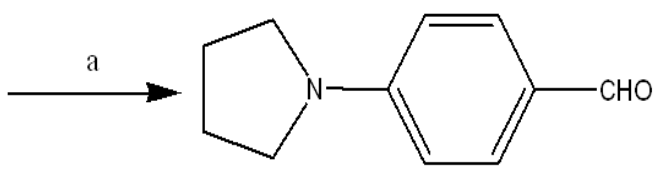

\section{Synthesis of (4-piperidine-I-yl-) benzaldehyde} [1c]

In $4.0 \mathrm{ml}$ of DMF of piperidine $(0.0 \mathrm{gm}$, $0.001 \mathrm{~mol}$ ) was dissolved. To this solution $\mathrm{K}_{2} \mathrm{CO}_{3}$ $(0.27 \mathrm{gm}, 0.002 \mathrm{~mol})$ was added and heated at $80^{\circ} \mathrm{C}$ with stirring. After 30 min 4-fluorobenzaldehyde

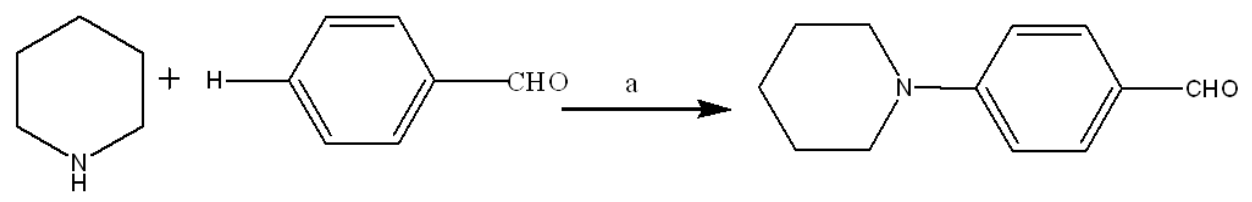

( $0.175 \mathrm{gm}, 0.001 \mathrm{~mol})$ was added and heating was continued for six hours. On completion of reaction, the reaction mixture was cooled and added drop wise to ice water. The separated product was filtered and dried. The product obtained was pure and used further without any purification. (M.P.-289 ${ }^{\circ} \mathrm{C}$ )

\section{Spectral Analysis}

IR: $\left(\mathrm{cm}^{-1}\right)$ : $1651(\mathrm{C}=\mathrm{O}), 1597(\mathrm{C}=\mathrm{C})$

${ }^{1} \mathrm{HNMR}$ (DMSO) $\delta$ ppm: $3.3\left(\mathrm{t}, 6 \mathrm{H}, \mathrm{CH}_{2}\right.$ ), 3.5 $\left(\mathrm{t}, 4 \mathrm{H}, \mathrm{CH}_{2}\right), 6.9$ (d, $2 \mathrm{H}$, aromatic), $7.6(\mathrm{t}, 2 \mathrm{H}$, aromatic) ,9.7 (s,1 $1 \mathrm{H}, \mathrm{CHO})$.

Mass: Mass (m/z): 189.

\section{CONCLUSION}

Our studies showed that $\mathrm{K}_{2} \mathrm{CO}_{3}$ was the most effective base, while the use of other bases such as $\mathrm{CsCO}_{3}$ and $\mathrm{Na}_{2} \mathrm{CO}_{3}$ was less successful. DMF was found to be the optimal solvent, although the use of DMSO was also effective.

In conclusion, the synthesis of wide variety of Nitrogen containing aldehydes is described with proper choice of base, solvent and temperature conditions. This work is underway to ameliorate difficulties which remain, especially in finding suitable reaction dynamics that efficiently increases the yield.

\section{ACKNOWLEDGEMENT}

The authors are thankful to the Principal, Yeshwant Mahavidyalaya, Nanded for providing lab facilities and Director SAIF, Chandigarh for spectral analysis.

\section{REFERENCES}

1. Newgwer M, Akademie Verlag $\mathrm{GmbH} 7^{\text {th }}$ edition Berlin (1994). (An international survey).
2. Ya SuhikoHigasio, Takayuki Shoji, Applied Catalyst A, General,.221(1-2): 197-207 (2001). 
3. Nai Y. J, Jiang Z. W, Wang Z. M, Li N, Li J.S, J. Parenter Enternal Nutr., 31(1): 18-25 (2001).

4. Kati W.M, Montgomery D, Carrick R,Gubareva L, Maring C, Mc.Daniel K,Steffy K, Molla A, Hayden F, Kempf D, Kohlbrenner W, Antimicrob. Agents. Chemother, 46(4): 101421 (2002).

5. De Geoy D.A, Chen H.J, Flossi W.J, Gram Povnik D.J., Yeung C.M, Klein L.L, Kempf D.J,J .Org .Chem,. 67: 5445-48 (2002).

6. Burten G, Ku TW, Carr T J, Kiesow T, Sarisky R.J, Lin Georke J, Baker A, Earnshaw D.L, Hoffmann G.A, Keenan R. M, Dhanak D, Biorg Med.Chem.Lett., 15: 1553-36 (2003).

7. Maring Clarenc J, Stoll Vincet S, Zhao Chen,Sun Minghua, Krueger Allan C, Stewart Kent D, Madigorn Darold L, Katiwarren M, Xu Yibo, Carrick Robert J,, J. of Med. Chem,.48(12): 3980-90 (2005).

8. Brater D.C. In : H. D. Humes (Ed), Kelley's Textbook of Internal medicine, $4^{\text {th }}$ Edition, 651 Philadelphia; Lippincott William and Wilkins.

9. Joe A Tran, Wanlong Jiang, Fabio C. Tucci, Beth A Fleck, JennywenYangSai, Ajay Madan, Ta Kung Chen, Stacy Markison, Alanc Foster et al., J. Med.Chem., 50(25): 6356 (2007).

10. Tomar Amita, Mall Maridula and VermaManju,,Int. J of Res. In Ayurveda and Pharmacy, 3(5): 1547-48 (2012).

11. Arthur R. Hancock, Steven A. Buckner, Michael E. Brune, Trimothy A. Esbenshade, Lynne M. Ireland, Shweta Katwala, Ivan Milicic et al., J. pharmacology and Exp. Therapeutics, 300(2): 478-86 (2001).

12. Smita A. Patel, Astrid G. Chapman, Joanne L. Graham, Brian S. Meddrum, Peter Frey, Epilepsy Research, 7(1): 3-10, (1990).

13. R. Soleymani, N. Niakan, S. Tayeb and S. Hakimi, Orient J. Chem., 28(1): 687-701 (2012).

13. S. K. Anandan et al..,Bioorgand Med. Chem. Lett. 21: 983 (2011).

14. L. F.Tietze and F. Major., Euro J. Org. Chem. 10: 2314-21 (2006).

15. George P Claxton, Lloyd Allen and J Martin Grisar,.,Org. Synth .Coll., 6: 968 (1988).

16. C. P. Meher, A.M. Rao, Md. Omar,.,AJPSR, 3(1): 43 (2013).

17. Shin-ya, Kim J.S, Furihata K, Hayakawa Y, Seto H, Tetrahedron Lett, 38: 7079 (1997). 